\title{
Tobacco control in the United States: Failure to protect the right to health
}

\section{Action on Smoking and Health ${ }^{1}$}

Co-Signing Organizations: African American Tobacco Control Leadership Council, Corporate Accountability International, Austrian Council on Smoking and Health, Centro de Investigacion para la Epidemia del Tabaquismo (CIET Uruguay), Cigarette Butt Pollution Project, Comité National Contre le Tabagisme (CNCT), European Network for Smoking and Tobacco Prevention (ENSP), International Union Against Tuberculosis and Lung Disease, Jeewaka Foundation, New Vois Association of the Phils. Inc. (NVAP), Public Health Advocacy Institute (PHAI), Southeast Asia Tobacco Control Alliance (SEATCA), Tanzania Tobacco Control Forum, UBINIG - Policy Research for Development Alternatives

ASH US has been working with partners around the world to use human rights measures to advance tobacco control. While the WHO FCTC does not have a robust reporting and enforcement mechanism, many human rights treaties do, and often, the subject matter of those treaties overlaps with the goals of tobacco control. Action on Smoking and Health (ASH), in partnership with 14 civil society organizations, submitted a report to the United Nations' Human Rights Council under its Universal Periodic Review (UPR) process regarding the United States' tobacco control efforts within a human rights framework. The Universal Periodic Review (UPR) gives countries the chance to share what actions they have taken to improve human rights in their countries and to fulfil the human rights obligations they have pledged to uphold. Under the UPR process, civil society organizations are also invited to submit reports to the Human Rights Council working group. The working group then refers information back to the Human Rights Council where recommendations are finalized and sent to countries to delineate what work is needed to improve their human rights record. This was a particularly important opportunity because the United States has signed few human rights treaties, and therefore is not reviewed by human rights processes frequently. This parallel report gave ASH and its partners the opportunity to point out to the government that tobacco, and the actions of the tobacco industry, prevents citizens of the United States from enjoying the highest attainable standard of health and disproportionately impacts people of certain races and socioeconomic condition.

\section{Summary}

1. Tobacco is often viewed as a problem that has been solved, particularly in the United States. However, tobacco kills more than 0.48 million Americans per year ${ }^{1}$. About 1 in 5 deaths in the United States is due to tobacco ${ }^{1}$.

2. Tobacco is a human rights issue and should be considered as part of the government's human rights obligations. Tobacco, and the actions of the tobacco industry, prevents citizens of the United States from enjoying the highest attainable standard of health and disproportionately impacts people of certain races and socioeconomic condition.
AFFILIATION

1 Action on Smoking and Health, Washington, United States

CORRESPONDENCE TO Action on Smoking and Health. ASH, 1250 Connecticut Ave, NW, 7th FI, Washington, D.C. 20036 (202) 659 - 4310, United States. E-mail: Romeo-StuppyK@ash.org, HuberL@ash.org

\section{KEYWORDS}

tobacco control, human rights, tobacco health impact

Received: 18 May 2020 Accepted: 18 May 2020 


\section{Relevant facts and statistics}

1. Smoking is the leading cause of preventable death in the United States ${ }^{1}$.

2. Smoking causes cancer, heart disease, stroke, lung diseases, diabetes, and chronic obstructive pulmonary disease (COPD), which includes emphysema and chronic bronchitis. Smoking also increases risk for tuberculosis, certain eye diseases, and problems of the immune system, including rheumatoid arthritis ${ }^{1}$.

3. Smoking costs the United States billions of dollars each year. Total economic cost of smoking is more than $\$ 300$ billion per year, including nearly $\$ 170$ billion in direct medical care for adults and more than $\$ 156$ billion in lost productivity due to premature death and exposure to secondhand smoke ${ }^{1}$.

4. If smoking continues at the current rate among U.S. youth, 5.6 million of today's Americans younger than 18 years of age are expected to die prematurely from a smoking-related illness. This represents about 1 in 13 Americans, aged 17 years or younger, who are alive today ${ }^{2}$.

5. Most adult cigarette smokers want to quit smoking. In 2015 , nearly 7 in $10(68.0 \%)$ adult cigarette smokers wanted to stop smoking. More than 5 in $10(55.4 \%)$ adult cigarette smokers had made a quit attempt in the past year ${ }^{1}$.

6. There are significant variations among smoking rates based on geography, race, and sexual orientation.

a. Geography. By U.S. Census region, prevalence of cigarette smoking among U.S. adults is highest among people living in the Midwest $(22.2 \%)$ and the South $(22.7 \%)$, and lowest among those living in the Northeast $(20.1 \%)$ and the West $(16.3 \%)^{3}$. Prevalence of cigarette smoking among U.S. adults is highest among those living in rural areas $(28.5 \%)$ and urban areas $(25.1 \%)^{3}$.

b. Race. There are over 40 million African Americans in the United States-approximately $13 \%$ of the U.S. population ${ }^{2}$. About $15 \%$ of African Americans smoke, a slightly higher percentage than all Americans (14\%). However, African Americans usually smoke fewer cigarettes and start smoking cigarettes at an older age than White Americans, but are more likely to die from smoking-related diseases $^{3}$. A large part of the reason for this discrepancy is menthol cigarettes. Menthol is a chemical that has a cooling effect on the mouth and throat of a smoker, which reduces the harshness of cigarette smoke, suppresses coughing, and makes inhaling cigarette smoke more comfortable ${ }^{4}$. Because menthol cigarettes are easier to inhale, menthol in cigarettes is thought to increase absorption of toxic chemicals in the smoker's body ${ }^{3}$. Research also shows that menthol cigarettes are likely more addictive than non-menthol. Nearly 9 in 10 African American smokers (88.5\%) aged 12 years and older prefer menthol cigarettes ${ }^{3}$. American Indians and Alaska Natives have the highest smoking rate of any racial or ethnic group, at approximately $21.9 \%$. A recent study also found American Indian and Alaska Native men and women have a higher percentage of smoking-related deaths from heart disease and stroke than White men and women ${ }^{5}$.

c. LGBTQI+. Overall, lesbian, gay, bisexual and transgender adults smoke at rates up to two and a half times higher than straight adults. In all, $20.6 \%$ of LGB adults and $35.5 \%$ of transgender adults smoke cigarettes compared to $14.9 \%$ of straight adults ${ }^{6}$.

\section{Legal obligations}

1. The United States has signed but not ratified the World Health Organization Framework Convention on Tobacco Control, despite the fact that the FCTC is one of the most quickly ratified treaties in history and currently has 181 state parties. While the FCTC was signed in 2004 by the Bush administration, it was never sent to the U.S. Senate for ratification.

2. While the United States is not party to many human rights treaties, it is bound by three that apply to tobacco: the Constitution of the World Health Organization, the Universal Declaration of Human Rights (UDHR), and the International Convention on the Elimination of All Forms of Racial Discrimination (ICERD).

3. The Constitution of the World Health Organization, the first international articulation of the right to health, states in its preamble that 'the enjoyment 
of the highest attainable standard of health is one of the fundamental rights of every human being without distinction of race, religion, political belief, economic or social condition'.

4. The 1948 Universal Declaration of Human Rights also mentioned health in Article 25: 'Everyone has the right to a standard of living adequate for the health and well-being of himself and of his family, including food, clothing, housing and medical care and necessary social services...'.

5. The International Convention on the Elimination of All Forms of Racial Discrimination (ICERD) was created with the goal of 'speedily eliminating racial discrimination throughout the world in all its forms and manifestations and of securing understanding of and respect for the dignity of the human person'7. It also recognizes the "right to public health"7. In 1966, the United States signed the Convention on the Elimination of Racial Discrimination (ICERD). It was ratified in 1994.

6. The U.N. Sustainable Development Goals (SDGs) were adopted by all United Nations Member States including the United States in 2015. President Obama emphasized the U.S. intention when he stated in front of the UN General Assembly that 'I am committing the United States to achieving the Sustainable Development Goals" ${ }^{8}$. The SDGs call on countries to reduce deaths from non-communicable diseases (including those caused by tobacco) by one-third by 2030 and more specifically, in Goal 3a, to 'strengthen the implementation of the FCTC'.

\section{U.S. laws and regulations}

1. In 2009, President Barack Obama signed into law the Family Smoking Prevention and Tobacco Control Act, giving the U.S. Food and Drug Administration (FDA) comprehensive authority to regulate the manufacturing, marketing, and sale of tobacco products. The new law represents the most sweeping action taken to date to reduce what remains the leading preventable cause of death in the United States?.

2. The 2009 law, among other things:

a. Restricts tobacco advertising and promotion in order to promote overall public health.

b. Stops illegal sales of tobacco products to minors.

c. Bans all cigarettes that have a characterizing flavor, including all fruit and candy flavors, other than tobacco or menthol.

d. Prohibits health claims about purported reduced risk products, where such claims are not scientifically proven or would cause net public health harms (e.g. by discouraging current tobacco users from quitting or encouraging new users to start).

e. Requires tobacco companies to disclose the contents of tobacco products, changes to their products, and research about the health effects of their products. Requires much larger, more visible, and more informative health warning labels, including color and graphics, on cigarette and smokeless tobacco product packages.

f. Similarly requires much larger, more visible, and more informative health warning labels on advertisements for cigarettes and smokeless tobacco.

g. Prohibits terms such as 'light,' 'mild' and 'low-tar' on tobacco product packages and advertisements, while authorizing the FDA to restrict additional terms in the future ${ }^{9}$.

3. The law also imposes certain limits on FDA authority. The agency cannot

a. Ban conventional tobacco products, such as cigarettes and smokeless tobacco, or require the total elimination of nicotine in tobacco products.

b. Increase the new federal minimum age of 18 years to a higher level.

c. Require prescriptions for the purchase of tobacco products.

d. Ban tobacco product sales in any particular type of sales outlet.

e. Regulate tobacco farming directly.

However, in all of these areas, the FDA could ask Congress to either take these actions or provide the agency with new authority to do them. Moreover, states have the authority to take such actions without congressional approval ${ }^{9}$.

\section{Recommendations}

The United States should:

1. Ratify and implement the obligations of the World Health Organization Framework Convention on Tobacco Control. 
2. Ban menthol, in order to comply with both the requirements of the WHO Constitution and ICERD.

a. Tobacco, and specifically menthol cigarettes, poses special challenges to the health and human rights of people of African descent in the United States.

b. Targeted marketing to African Americans is hugely problematic. Historically, the tobacco industry has used opportunities such as cultural events to promote its products ${ }^{10}$. The industry has also placed more advertisements in African American publications for its mentholated products ${ }^{10}$. In addition, a 2017 nationwide study found that stores in neighborhoods with the highest proportion of African Americans have more than double the odds of advertising price promotions for tobacco products, compared to stores in neighborhoods with the lowest proportion of African Americans ${ }^{11}$. Areas with larger racial minority populations tend to have a higher density of tobacco retailers, further increasing exposure to tobacco advertising ${ }^{3}$. Within those stores, menthol products are given more shelf space in retail outlets within African American and other minority neighborhoods ${ }^{3}$.

c. In addition to racial minorities, the tobacco industry encourages menthol cigarette use among LGBT populations. Approximately 36\% of LGBT smokers report smoking menthol cigarettes compared to $29 \%$ of heterosexual/ straight smokers ${ }^{12}$.

d. Tobacco companies also began to advertise in 'gay press' publications in the early 1990s, often depicting tobacco use as a 'normal' part of LGBT life. Many ads for products other than cigarettes glamorized smoking, and many articles having nothing to do with smoking were shown with tobacco images. In 1995, the tobacco company R.J. Reynolds created a marketing strategy called 'Project SCUM' (SubCulture Urban Marketing) to boost cigarette sales by targeting gay men and homeless individuals with advertisements and displays placed in communities and stores. On top of donations, giveaways and increased advertising, the tobacco industry made community outreach efforts, such as hosting local promotions like
'LGBT bar nights' featuring specific cigarette brands ${ }^{13}$.

e. The tobacco industry has clearly and openly used menthol to target African Americans and the LGBTQI+ community for decades, making it more difficult for members of these populations in the United States to 'achieve the highest attainable standard of physical and mental health'. ${ }^{14}$

3. Raise tobacco taxes. The WHO benchmark is that a minimum of $70 \%$ of the final price of cigarette consist of an excise tax. The U.S. Federal government's tax is approximately $38 \%{ }^{15}$. Increasing tobacco taxes is very effective; every 10 per cent increase in the price of cigarettes reduces consumption by about 4 per cent among adults and about 7 per cent among youth ${ }^{16}$.

4. Increase cessation support. All health insurance programs funded and run by the federal government should cover a comprehensive tobacco cessation benefit ${ }^{17}$.

5. Reduce the supply of cigarettes, through retailer licensing or other measures. The U.S. has done very little to restrict the supply of tobacco products. There are far more outlets for tobacco products than there are for milk, for example. Only a few local jurisdictions have passed laws restricting the number of tobacco sales licenses. At the federal level and in many states, no license is required at all.

6. Exclude the tobacco industry from discussions on tobacco control, due to their long history of interference and manipulation. In the U.S. the tobacco industry operates at the federal, state and local levels. Federally, the industry has been invited to weigh in on the Food and Drug Administration's (FDA) regulatory approach to tobacco and e-cigarettes. The FDA Tobacco Products Scientific Advisory Committee is composed of three nonvoting members who have an identified interest with the tobacco industry including manufacturing (large industry and small business) and growing ${ }^{18}$. Nationwide all 50 states have at least one lobbyist registered to represent a tobacco company ${ }^{19}$. The industry spent over $\$ 46$ million in federal lobbying alone between 2017 and 2018 and utilized lobbyists and multiple front groups to thwart state and local legislation, including raising the age of 
purchase to 21 years, flavored tobacco (including menthol) and tax bills ${ }^{20-23}$. The industry also continued its trend of drafting sample legislation with pre-emptive language (i.e. removing the right of lower governments to enact stricter regulations) and delaying and weakening state and federal action and authority. This includes the newly created Foundation for a Smoke-Free World, which has been recognized as nothing more than a front for the tobacco industry ${ }^{24}$. The tobacco industry and their paid lobbyists should not be involved in drafting the legislation meant to regulate their products and reduce death and disease. This includes electronic cigarette companies.

7. Increase transparency. Federally, the FDA does not have policies in place to: 1) disclose all public comments on FDA dockets, and 2) to provide copies of communications between the FDA and tobacco industry representatives. In most states, lawmakers are not typically required to disclose the full nature of their informal interactions with lobbyists ${ }^{25}$. However, there are other government disclosure rules such as annual tobacco company registration under The Family Smoking Prevention and Tobacco Control Act, registration of firms with in-house lobbyists when income/expense minimums are met under the Federal Lobbying Disclosure Act, permit requirements under the Alcohol and Tobacco Tax and Trade Bureau (ATB) and permit requirements for businesses related to the manufacture of tobacco under Chapter 52 of the Internal Revenue Service (IRS) Code (26-28). All 50 states do provide public access to registration information for lobbyists and/ or entities who contract for lobbying services ${ }^{19}$. A government code of conduct for public officials when dealing with the industry, policies disallowing the acceptance of contributions/gifts from the tobacco industry to government agencies and officials and programs to help raise awareness within government departments on FCTC Article 5.3 guidelines could not be identified.

8. Regulate electronic cigarettes, specifically by banning all flavors, including mint and menthol. More recently, in August 2019, the United States saw the first confirmed death due to using a vaping device. In response, President Trump announced that the Food and Drug Administration will issue a policy in October 2019 to remove flavored vaping products from the market ${ }^{29}$. The epidemic of electronic cigarettes is alarming and presents a new challenge. The regulation of these products will greatly impact the protection of children, the most vulnerable population to the marketing tactics of these products.

\section{REFERENCES}

1. Centers for Disease Control and Prevention. Smoking and Tobacco Use: Fast Facts. https://www.cdc.gov/ tobacco/data_statistics/fact_sheets/fast_facts/index.htm. Published November 15, 2019. Accessed May 18, 2020.

2. United States Census Bureau. American Community Survey (ACS). https://www.census.gov/programssurveys/acs. Accessed May 18, 2020.

3. Centers for Disease Control and Prevention. African Americans and Tobacco Use. Accessed May 18, 2020.

4. Truth Initiative. Menthol: Facts, Stats, and Regulations. https://truthinitiative.org/research-resources/traditionaltobacco-products/menthol-facts-stats-and-regulations. Published August 31, 2018. Accessed May 18, 2020.

5. American Lung Association. Tobacco Use in Racial and Ethnic Populations. https://www.lung.org/quit-smoking/ smoking-facts/impact-of-tobacco-use/tobacco-use-racialand-ethnic. Published February 20, 2019. Accessed May $18,2020$.

6. Truth Initiative. Tobacco Use in LGBT Communities. https://truthinitiative.org/research-resources/targetedcommunities/tobacco-use-lgbt-communities. Published February 13, 2018. Accessed May 18, 2020.

7. UN General Assembly. International Convention on the Elimination of All Forms of Racial Discrimination. United Nations, Treaty Series, vol. 660, p. 195. https:// www.refworld.org/docid/3ae6b3940.html. Published December 21, 1965. Accessed May 18, 2020.

8. The White House. Remarks by the President on Sustainable Development Goals. https://www. whitehouse.gov/the-press-office/2015/09/27/remarkspresident-sustainable-development-goals. Published September 27, 2015. Accessed May 18, 2020.

9. Tobacco Control Legal Consortium. Federal Regulation of Tobacco: A Summary. https://www. publichealthlawcenter.org/sites/default/files/resources/ tclc-fda-summary.pdf. Published July 2009. Accessed May 18, 2020.

10. Centers for Disease Control and Prevention. Tobacco Use Among U.S. Racial/Ethnic Minority Groups - African Americans, American Indians and Alaska Natives, Asian Americans and Pacific Islanders, Hispanics: A Report of the Surgeon General. Atlanta, Georgia: U.S. Department of Health and Human Services, Centers for Disease Control and Prevention, National Center for Chronic Disease Prevention and Health Promotion, Office on 
Smoking and Health, 1998. https://www.cdc.gov/ tobacco/data_statistics/sgr/1998/complete_report/pdfs/ complete_report.pdf. Accessed May 18, 2020.

11. Campaign for Tobacco Free Kids. Marketing Menthol: The History of Target Menthol to African Americans. https://www.tobaccofreekids.org/assets/factsheets/0400. pdf. Published November 15, 2018. Accessed May 18, 2020.

12. Centers for Disease Control and Prevention. Lesbian, Gay, Bisexual, and Transgender Persons and Tobacco Use. https://www.cdc.gov/tobacco/disparities/lgbt/index.htm. Accessed May 18, 2020.

13. Truth Initiative. Tobacco use in LGBT communities. https://truthinitiative.org/research-resources/targetedcommunities/tobacco-use-lgbt-communities. Published February 13, 2018. Accessed May 18, 2020.

14. UN General Assembly. International Covenant on Economic, Social and Cultural Rights. United Nations, Treaty Series, vol. 993, p. 3. http://www.refworld.org/ docid/3ae6b36c0.html. Accessed May 18, 2020.

15. American Cancer Society. The Tobacco Atlas: United States 2019. https://tobaccoatlas.org/country/usa/. Accessed May 18, 2020.

16. American Lung Association. Cigarette and Tobacco Taxes. https://www.lung.org/our-initiatives/tobacco/taxes/. Updated March 25, 2020. Accessed May 18, 2020.

17. American Lung Association. Federal Cessation Coverage. https://www.lung.org/our-initiatives/tobacco/cessationand-prevention/federal-cessation-coverage.html. Updated March 10, 2020. Accessed May 18, 2020.

18. US Food and Drug Administration. Tobacco Products Scientific Advisory Committee. https://www.fda.gov/ advisorycommittees/committeesmeetingmaterials/ tobaccoproductsscientificadvisorycommittee/default.htm. Published January 23, 2018. Accessed May 18, 2020.

19. Matheny JD, Stevens EM, Chen S, Christiansen BA, Kowitt SD, Osman A, Vidrine DJ. The Rico Verdict and Corrective Statements: Catalysts for Policy Change? Tob Regul Sci. 2019;5(3):206-228. doi:10.18001/trs.5.3.1

20. OpenSecrets. Influence \& Lobbying Industries: Tobacco. https://www.opensecrets.org/lobby/indusclient. php?id=A02\&year=2017. Accessed May 18, 2020.

21. OpenSecrets. Influence \& Lobbying Industries: Tobacco 2018. https://www.opensecrets.org/industries/lobbying. php?cycle=2018\&ind=A02. Accessed May 18, 2020.

22. Campaign for Tobacco Free Kids. Tobacco Industry Interference with State Policy. https://www. tobaccofreekids.org/assets/factsheets/0389.pdf. Accessed May 18, 2020.

23. Glenza J, Juweek A. Free-market Groups and the Tobacco Industry - Full Database. https://www.theguardian.com/ world/ng-interactive/2019/jan/23/free-market-thinktankstobacco-control-polices-database\#0/?americans-for-taxreform. Accessed May 18, 2020.

24. World Health Organization. WHO Statement on Philip
Morris funded Foundation for a Smoke-Free World. https://www.who.int/news-room/detail/28-09-2017who-statement-on-philip-morris-funded-foundationfor-a-smoke-free-world. Published September 28, 2018. Accessed May 18, 2020.

25. Tobacco Control Legal Consortium. Smoke and Subterfuge: A Look at Tobacco Industry Tactics. https:// www.publichealthlawcenter.org/sites/default/files/ resources/tclc-legal-update-fall-2013.pdf. Published 2013. Accessed May 18, 2020.

26. Tobacco Products and Cigarette Papers and Tubes. In: Internal Revenue Code, 26 USC Ch. 52. http://uscode. house.gov/view.xhtml?path=/prelim@title26/subtitleE/ chapter52\&edition=prelim. Accessed May 18, 2020.

27. US Food and Drug Administration. Family Smoking Prevention and Tobacco Control Act - An Overview. https://www.fda.gov/tobacco-products/rules-regulationsand-guidance/family-smoking-prevention-and-tobaccocontrol-act-overview. Accessed May 18, 2020.

28. United States Senate. Lobbying Disclosure Act (LDA). https://www.senate.gov/pagelayout/legislative/g_three_ sections_with_teasers/lobbyingdisc.htm\#lobbyingdisc=lda. Published April 12, 2019. Accessed May 18, 2020.

29. Harris R, Wroth C. FDA To Banish Flavored E-Cigarettes To Combat Youth Vaping. https://www.npr.org/sections/ health-shots/2019/09/11/759851853/fda-to-banishflavored-e-cigarettes-to-combat-youth-vaping. Published September 11, 2019. Accessed May 18, 2020.

CONFLICTS OF INTEREST

The authors have completed and submitted the ICMJE Form for Disclosure of Potential Conflicts of Interest and none was reported.

FUNDING

There was no source of funding for this research.

PROVENANCE AND PEER REVIEW

Commissioned; internally peer reviewed. 